\title{
PENINGKATAN TRANSFER OKSIGEN PADA CASCADE AERATOR DENGAN INOVASI BAK TERJUNAN
}

\author{
OXYGEN TRANSFERS INCREASING IN CASCADE AERATOR WITH WATERFALL AERATION \\ BASIN INOVATIONS
}

\author{
Indra Laksana ${ }^{1}$, Mahmud ${ }^{2}$ dan Nopi Stiyati Prihatini ${ }^{3}$ \\ Program Studi Teknik Lingkungan, Fakultas Teknik, Universitas Lambung Mangkurat, JL. A. Yani \\ Km. 36 Banjarbaru, Kalimantan Selatan, 70714, Indonesia \\ E-mail: indrazeinlaksana@gmail.com
}

\begin{abstract}
ASBTRAK
Aerasi adalah teknologi pengolahan air dengan cara mentransfer oksigen ke dalam air. Cascade aerasi telah terbukti memiliki kelebihan dalam hal sisi ekonomi dan pengoperasian. Pengembangan cascade aerator banyak dilakukan untuk meningkatkan penyisihan bahan pencemar maupun untuk meningkatkan transfer oksigen. Penelitian ini bertujuan untuk mengalisis pengaruh perlakukan perubahan pada bak aerasi cascade aerator terhadap peningkatan kinerja cascade aerator pada proses aerasi dengan cascade aerator satu tingkat berbasis weir untuk mengetahui variasi yang terbaik. Proses aerasi dilakukan dengan mengalirkan air pada cascade aerator dengan debit 60 L/menit selama 4 menit dimana setiap 30 detik dilakukan pengukuran nilai DO, suhu dan tekanan udara. Hasil penelitian menunjukan bahwa melakukan modifikasi pada bak terjunan mampu meningkatkan kinerja cascade aerator dimana variasi terbaik yaitu variasi 3 yaitu inovasi dengan menambahkan slooping spillway dengan chute blocks dengan rata-rata selisih peningkatan sebesar $3,08 \mathrm{mg} / \mathrm{L}$, $r$ sebesar 12,8 , efisiensi sebesar $85 \%$ dan efisiensi pada suhu $20^{\circ} \mathrm{C}$ sebesar $81 \%$.
\end{abstract}

Kata Kunci: Aerasi, Cascade Aerasi, Inovasi Bak Terjunan, Efisiensi

\begin{abstract}
Aeration is a water treatment technology by transferring oxygen into water. Cascade aeration has proven advantages in terms of economy and operation. The development of cascade aerators is mostly done to increase the elimination of pollutants and to increase oxygen transfer. This study aims to analyze the effect of treating changes in cascade aerator aeration tanks on improving the performance of cascade aerators in the aeration process with a weir-based one level cascade aerator to determine the best variation. The aeration process is carried out by flowing water into the cascade aerator with a discharge of $60 \mathrm{~L} / \mathrm{min}$ for 4 minutes where every 30 seconds measurements are taken DO, temperature and air pressure. The results showed that making modifications to the waterfall basin can improve cascade aerator performance where the best variation is variation 3, namely innovation by adding slooping spillway with chute blocks with an average difference of increase of $3.08 \mathrm{mg} / \mathrm{L}, \mathrm{r}$ of 12.8, efficiency by $85 \%$ and efficiency at $2{ }^{\circ} \mathrm{C}$ by $81 \%$.
\end{abstract}

Keywords: Aeration, Cascade Aeration, Inovation on Waterfall Aeration Basin, Efficiency 


\section{PENDAHULUAN}

Aerasi atau disebut juga transfer gas pada proses transfer oksigen adalah penambahan oksigen ke dalam air. Aerasi biasa dimanfaatkan untuk mengolah air yang mengandung besi mangan. Aerasi memiliki keuntungan dalam hal ekonomi dan operasi yang mudah dan efektif. Selain itu, aerasi juga dipakai dalam proses penyisihan gas-gas seperti metana, karbon dioksida atau hydrogen sulfida, juga bau-bau dan rasa (fair, 1968). Beberapa jenis aerator yang berkembang antara lain yaitu gravity aerator, spray aerator, bubble aeration dan mechanical aerator (Metcalf dan Eddy, 2003).

Cascade aerator adalah salah satu Teknik aerasi dengan mengandalkan tenaga gravitasi dengan mengalirkan air dari atas ke bawa sambal melewatkannya pada terjunan berupa anak tangga. Aerasi ini tidak memerlukan biaya yang lebih Proses aerasi yang terjadi pada cascade aerator yaitu proses reaerasi dan deaerasi. Reaerasi adalah proses bertambahnya gas ke dalam aliran air akibat tumbukan dalam hal ini adalah turbulensi air. Sedangkan deaerasi adalah proses berkurangnya atau menghilangnya gas-gas dari aliran air akibat terjadinya kontak permukaan air terhadap udara. Untuk meningkatkan kadar oksigen dalam air, maka dilakukan peningkatan derajat reaerasi.

Hal mendasar yang mempengaruhi efesiensi dari cascade aerator adalah turbulensi air. Semakin tinggi turbulensi air maka semakin tinggi pula derajat reaerasi yang menyatakan kenaikan derajat oksigen terlarut dalam air. Menurut Benefield (1980), keberhasilan proses aerasi tergantung pada berapa besarnya nilai suhu, kejenuhan oksigen, karakteristik air dan turbulensi air. Menurut Kindsvaler dalam ASCE (1991), ada beberapa proses fisik dasar dan hidrodinamik yang mengakibatkan transfer gas pada alat berbasis hidrolik yaitu pencampuran turbulen (turbulent mixing) pada permukaan air dengan badan air pada aliran, peningkatan transfer massa dari terbentuknya gelembung udara (bubble) dan akibat tekanan hidrostatik dari tailwater.

Cascade aerator menggunakan bak bendung memang lebih baik daripada tanpa menggunakan bak bendung karena bak bendung akan menghasilkan turbulensi air yang lebih baik dan menghasilkan gelembung udara yang lebih banyak. Selain itu, bak bendung dapat dimodifikasi untuk meningkatkan pencampuran turbelensi dan jumlah gelembung yang dihasilkan. Dalam penelitian ini, ingin diketahui pengaruh penambahan pemecah aliran, spillway dan chute blocks pada bak terjunan terhadap kinerja cascade aerator.

Cascade aerator berkonsep weir adalah cascade aerator yang terinspirasi dari konsep aerasi pada bendungan (DAM). Pengukuran kinerja cascade ini dapat dilakukan dengan membandingkan antara konsentrasi awal dan akhir melalui persamaan:

$$
\Delta C=C_{d}-C_{u}
$$

Setelah berkembangnya metode cascade aerasi, Gameson (1957), mengemukakan metode pengukuran cascade aerator weir yang diukur dengan persamaan:

$$
r=\frac{C s-C u}{C s-C d}
$$

Kemudian Guliver dan Rindels (1993) mengekspresikan suatu persamaan untuk mengukur kinerja cascade aerasi berupa efisiensi yang juga sebelumnya pernah dikemukaan oleh Gameson (1957) dengan persamaan:

$$
E=1-\frac{C s-C d}{C s-C u}=\frac{C d-C u}{C s-C u}
$$

Guliver dan Rindels (1993) mengemukakan cara pengukuran untuk memperkirakan nilai suatu efisiensi cascade aerasi pada berbagai suhu pengukuran sehingga dapat dianggap memiliki suhu yang sama. Yaitu dengan mengkonversi nilai efiseiensi melalui suatu pengubah, dan pengubah tersebut yaitu $\mathrm{f}$ dengan persamaan:

$$
1-E_{20}=(1-E)^{1 / f}
$$


Dimana:

$$
f=1.0+0.02103(T-20)+8.261 \times 10^{-5}(T-20)^{2}
$$

\section{METODOLOGI PENELITIAN}

Penelitian ini dilakukan dalam skala laboratorium, dengan tujuan penelitian untuk mengidentifikasi pengaruh penambahan pemecah aliran, slooping spillways, chute blocks dan horizontal plate blocks pada bak terjunan cascade aerator terhadap peningkatan kadar DO dan KLa serta efisiensi cascade aerator.

Penelitian di awali dengan pembuatan alat cascade aerator. Pembuatan alat diawali dengan membuat pondasi dengan bahan kayu, kemudian membuat cascade dengan bahan kaca tebal $10 \mathrm{~mm}$. Tinggi jatuh air pada cascade dirancang setinggi $90 \mathrm{~cm}$ sebanyak 1 step dengan kedalaman bak sebesar 20 $\mathrm{cm}$. Cascade ini menggunakan pompa sebagai pendorong air ke bak pelimpah yang diletakkan di bawah cascade. Selain cascade, juga dipersiapkan berbagai alat variabel seperti pemecah aliran, slooping spillways, chute blocks dan horizontal plate blocks yang terbuat dari bahan kaca. Desain alat dapat dilihat pada Gambar 1 hingga 3.

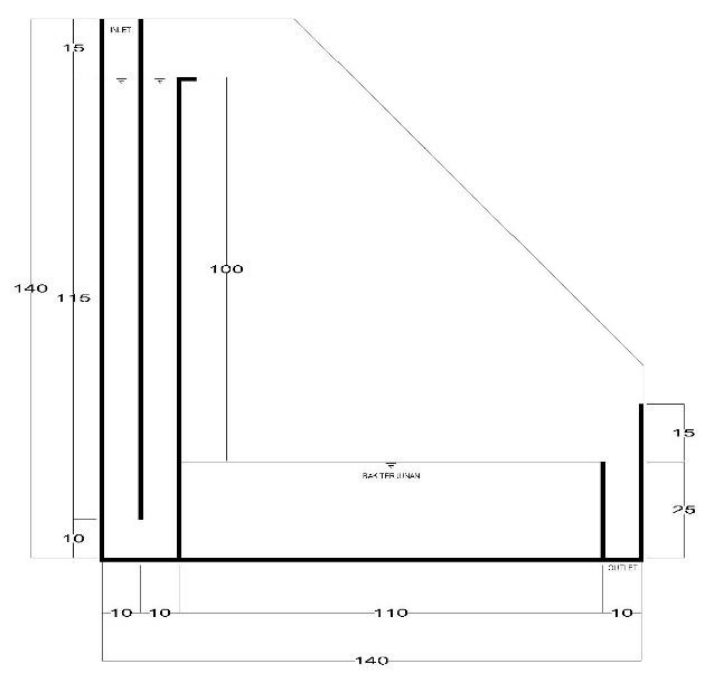

Gambar 1 Rancangan Alat Cascade Aerator

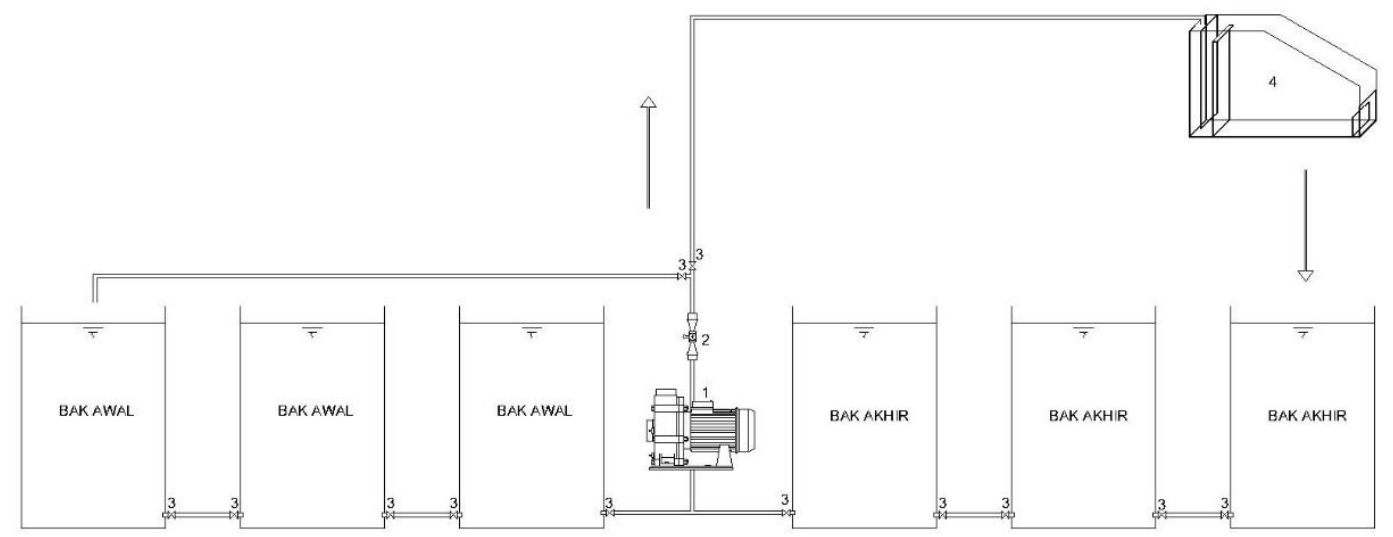

Gambar 2 Skema Peralatan Tampak Samping 


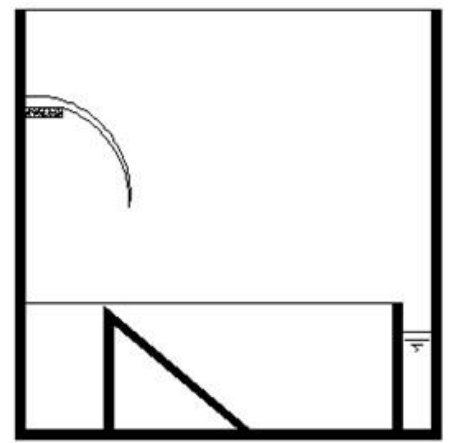

(Variasi 1)

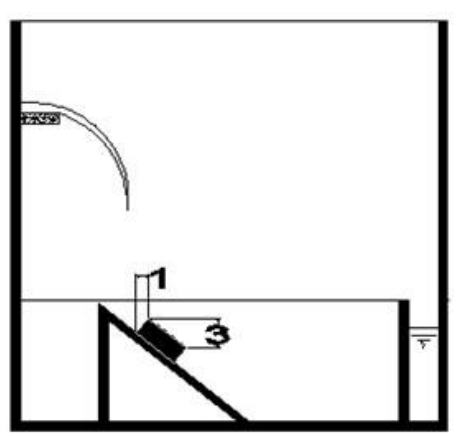

(Variasi 3)

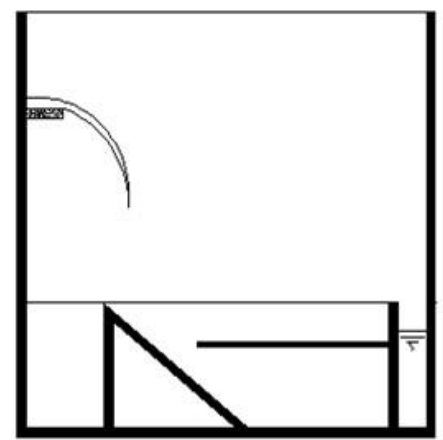

(Variasi 2)

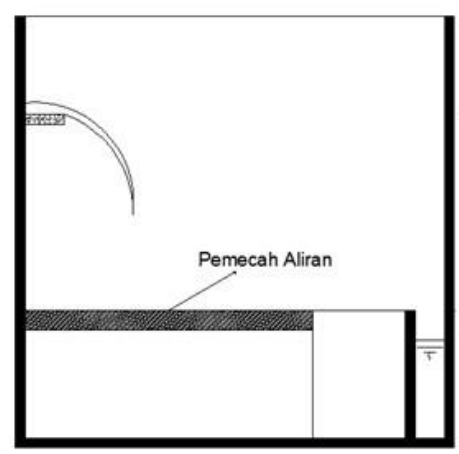

(Variasi 4)

Gambar 3 Skema Rancang Alat Masing-masing Variasi

Sampel air artifisial sebagai sampel penelitian dibuat dari air akuades yang dihomogenkan pada wadah bak plastik. Pengukuran kandungan DO awal dilakukan untuk mengetahui kadar DO sebelum sampel melewati cascade aerator. Pengukuran DO dilakukan menggunakan DO meter yang telah dikalibrasi terlebih dahulu. Metode pengukuran dilakukan dengan memasukan sensor pada DO meter pada air sampel sebelum sampel melewati cascade aerator, kemudian hasil dapat diketahui dengan melihat berapa nilai yang tertera pada layar digital DO meter. Selain nilai DO, juga diukur nilai suhu dan tekanan yang dibutuhkan dalam perhitungan nilai oksigen jenuh.

Prosedur penelitian yang dilakukan yaitu, pertama memasukkan sampel air artifisial ke dalam bak penampung. Kemudian mendiamkan sampel agar suhu menjadi homogen dengan suhu ruangan. Setelah itu sampel dialirkan pada aerator dengan bantuan duah buah pompa dengan debit maksimal yaitu $60 \mathrm{~L} /$ menit. Pengaliran dilakukan selama 4 menit dan kemudian dilakukan pengukuran konsentrasi DO serta suhu dan tekanan barometrik di effluen menggunakan DO meter setiap 0,5 menit. Percobaan ini dilakukan sebanyak 5 kali pengulangan. Dari percobaan ini didapatkan output berupa efisiensi cascade aerator.

\section{HASIL DAN PEMBAHASAN}

\section{Perbandingan Kinerja Aerator Terhadap Peningkatan DO}

Pengujian dilakukan sebelum dan setelah air sampel melewati cascade aerator untuk mengetahui perubahan kadar DO dalam air sampel. Hasil pengukuran pada penelitian ini disajikan pada Tabel 1. 
Tabel 1. Hasil Pengukuran Nilai DO Sebelum dan Sesudah Dilakukan Aerasi pada Setiap Variasi

\begin{tabular}{|c|c|c|c|c|c|c|}
\hline Perlakuan & Percobaan & $\mathbf{T}\left({ }^{\circ} \mathbf{C}\right)$ & $\mathbf{P}(\mathrm{mmHg})$ & $\mathrm{Cu}(\mathrm{mg} / \mathrm{L})$ & $\mathrm{Cd}(\mathrm{mg} / \mathrm{L})$ & Selisih (mg/L) \\
\hline \multirow{5}{*}{ Kontrol } & 1 & 27.70 & 753.40 & 4.48 & 7.05 & 2.57 \\
\hline & 2 & 27.45 & 753.83 & 4.52 & 7.11 & 2.59 \\
\hline & 3 & 28.43 & 751.59 & 4.23 & 7.26 & 3.03 \\
\hline & 4 & 28.18 & 753.80 & 4.55 & 6.98 & 2.43 \\
\hline & 5 & 28.08 & 752.88 & 3.82 & 6.90 & 3.08 \\
\hline \multirow{5}{*}{ Variasi 1} & 1 & 27.40 & 754.15 & 4.50 & 7.26 & 2.76 \\
\hline & 2 & 27.30 & 754.28 & 4.47 & 7.26 & 2.79 \\
\hline & 3 & 28.40 & 754.21 & 4.26 & 7.43 & 3.17 \\
\hline & 4 & 28.20 & 752.96 & 4.60 & 7.25 & 2.65 \\
\hline & 5 & 27.85 & 753.50 & 3.85 & 7.18 & 3.33 \\
\hline \multirow{5}{*}{ Variasi 2} & 1 & 27.10 & 754.90 & 4.52 & 7.25 & 2.73 \\
\hline & 2 & 27.00 & 754.90 & 4.48 & 7.14 & 2.66 \\
\hline & 3 & 28.30 & 754.15 & 4.21 & 7.32 & 3.11 \\
\hline & 4 & 28.13 & 752.33 & 4.47 & 7.15 & 2.68 \\
\hline & 5 & 27.60 & 752.33 & 3.89 & 7.11 & 3.22 \\
\hline \multirow{5}{*}{ Variasi 3} & 1 & 26.80 & 754.50 & 4.46 & 7.48 & 3.02 \\
\hline & 2 & 26.70 & 754.44 & 4.48 & 7.43 & 2.95 \\
\hline & 3 & 28.40 & 752.01 & 4.23 & 7.49 & 3.26 \\
\hline & 4 & 28.14 & 754.53 & 4.54 & 7.31 & 2.77 \\
\hline & 5 & 27.60 & 754.13 & 3.88 & 7.29 & 3.41 \\
\hline \multirow{5}{*}{ Variasi 4} & 1 & 26.50 & 754.30 & 4.48 & 7.37 & 2.89 \\
\hline & 2 & 26.40 & 754.30 & 4.50 & 7.41 & 2.91 \\
\hline & 3 & 28.40 & 753.20 & 4.25 & 7.34 & 3.09 \\
\hline & 4 & 28.10 & 754.16 & 4.57 & 7.16 & 2.59 \\
\hline & 5 & 28.20 & 752.66 & 3.80 & 7.07 & 3.27 \\
\hline
\end{tabular}

Elevasi dan lokasi percobaan sangat mempengaruhi hasil pengukuran baik itu tekanan udara, suhu air maupun kelarutan Cs. Lokasi percobaan memiliki ketinggian $36 \mathrm{~m}$ di atas permukaan laut dengan tekanan yang lebih rendah dari pada tekanan udara normal $(760 \mathrm{mmHg})$ yaitu antara 751,59 hingga $754,90 \mathrm{mmHg}$. Tekanan udara yang berada di bawah tekanan udara normal tersebut mempengaruhi suhu air pada percobaan yaitu sebesar 26,40 hingga $28,43^{\circ} \mathrm{C}$.

Nilai DO sebelum dilakukan aerasi $(\mathrm{Cu})$ berkisar dari 3,80 hingga 4,60 mg/L, nilai ini lebih rendah dibandingkan pengukuran yang dilakukan oleh Abuzar (2012) dan Kim (2001) dimana rentang DO awal pada sampel sebelum aerasi pada Abuzar (2012) yaitu 5,97 mg/L hingga 6,1 mg/L dan pada Kim (2001) yaitu 7,7 mg/l hingga 9,1 mg/L. Hal ini dikarenakan perbedaan lokasi penelitian sehingga mempengaruhi suhu air pada saat diteliti, dimana penelitian dilakukan oleh Abuzar (2012) memiliki suhu berkisar 22,9 hingga $23,3^{\circ} \mathrm{C}$ dan Kim (2001) berkisar di suhu 15 hingga $18,6^{\circ} \mathrm{C}$. Suhu yang rendah menyebabkan naiknya nilai konsentrasi oksigen terlaut jenuh sehingga air pada suhu air yang lebih rendah memiliki nilai DO yang lebih baik daripada air dengan suhu yang memiliki suhu lebih tinggi seperti yang dikatakan oleh Bennefield (1980). Kemudian bila dibandingkan nilai Cu dengan penelitian yang dilakukan oleh Yatie (2012), nilai ini termasuk besar karena pada penelitian Yaite nilai DO sebelum dilakukan aerasi berkisar antara $0,54 \mathrm{mg} / \mathrm{L}$ hinga $1,05 \mathrm{mg} / \mathrm{L}$. Perbedaan ini terjadi karena pada Yatie (2012) dilakukan pelepasan gas sehingga mampu menurunkan kadar DO mendekati habis sedangkan pada penelitian ini tidak dilakukan pelepasan gas. 
Setelah dilakukan aerasi nilai DO setelah aerasi (Cd) berkisar dari 6,90 hingga 7,49 mg/L. Sedangkan selisih peningkatan DO sebelum dan sesudah berkisar antara 2,43 mg/L hingga $3.41 \mathrm{mg} / \mathrm{L}$. Pada penelitian Kim (2001) yang melakukan teknis aerasi yang sama yaitu cascade aerator berbasis weir, selisih yang didapatkan lebih tinggi dimana Kim (2001) mendapat selisih tertinggi yaitu 2,9 mg/L. hal ini karena Kim (2001) menggunakan cascade aerator yang ukurannya lebih besar tetapi debitnya lebih kecil sehingga dalam hal tekanan permukaan lebih kecil dibandingkan dengan cascade aerator yang dipakai pada penelitian ini.

Berdasarkan Tabel 1, variasi 3 (slooping spillways dengan chute blocks) mampu meningkatkan kadar DO dalam air sangat baik dibandingkan dengan variasi yang lain dimana menaikan kadar $\mathrm{Cu}$ dengan selisih kenaikan tertinggi yaitu 3,41 mg/L dengan DO maksimal yaitu sebesar 7,49 mg/L. Kemudian rata-rata kinerja peningkatan DO cascade aerasi disajikan pada Tabel 2.

Tabel 2. Rata-rata Kenaikan Nilai DO Sebelum dan Sesudah Dilakukan Aerasi pada Setiap Variasi

\begin{tabular}{cccc}
\hline Perlakukan & $\mathbf{C u}(\mathbf{m g} / \mathbf{L})$ & Cd $(\mathbf{m g} / \mathbf{L})$ & Selisih $(\mathbf{m g} / \mathbf{L})$ \\
\hline Kontrol & 4.32 & 7.06 & 2.74 \\
Variasi 1 & 4.34 & 7.27 & 2.94 \\
Variasi 2 & 4.31 & 7.19 & 2.88 \\
Variasi 3 & 4.32 & 7.40 & 3.08 \\
Variasi 4 & 4.32 & 7.27 & 2.95 \\
\hline
\end{tabular}

Berdasarkan Tabel 2, secara rata-rata kinerja variasi 3 juga terbaik dengan rata-rata selisih 3,08 mg/L dan rata-rata $\mathrm{Cd}$ mencapai 7,40 mg/L dari $\mathrm{Cu} 4.32 \mathrm{mg} / \mathrm{L}$. Hasil yang didapat juga jauh lebih baik dibandingkan dengan kontrol yang hanya memiliki rata-rata kenaikan sebesar 2,74 mg/L.

\section{Tingkat Efisiensi Kinerja Cascade Aerator}

Kinerja cascade aerator berbentuk weir dapat digambarkan dengan defisit rasio (r), efisiensi (E) dam efisiensi pada suhu $20^{\circ} \mathrm{C}$ yang disajikan pada Tabel 3.

Tabel 3 Hasil Perhitungan Nilai Defisit Rasio (r), Efisiensi (E) dan Efisiensi pada Suhu $20^{\circ} \mathrm{C}\left(\mathrm{E}_{20}\right)$ pada Setiap Variasi

\begin{tabular}{ccccccc}
\hline Perlakuan & Percobaan & Cs $(\mathbf{m g} / \mathbf{L})$ & $\mathbf{r}$ & $\mathbf{E}$ & $\mathbf{f}$ & $\mathbf{E}_{\mathbf{2 0}}$ \\
\hline \multirow{5}{*}{ Kontrol } & 1 & 7.89 & 4.06 & 0.75 & 1.17 & 0.70 \\
& 2 & 7.94 & 4.13 & 0.76 & 1.16 & 0.71 \\
& 3 & 7.77 & 7.01 & 0.86 & 1.18 & 0.81 \\
& 4 & 7.83 & 3.86 & 0.74 & 1.18 & 0.68 \\
& 5 & 7.83 & 4.29 & 0.77 & 1.18 & 0.71 \\
Variasi 1 & 1 & 7.95 & 5.00 & 0.80 & 1.16 & 0.75 \\
& 2 & 7.96 & 4.97 & 0.80 & 1.16 & 0.75 \\
& 3 & 7.80 & 9.62 & 0.90 & 1.18 & 0.85 \\
& 4 & 7.81 & 5.71 & 0.82 & 1.18 & 0.77 \\
& 5 & 7.87 & 5.78 & 0.83 & 1.17 & 0.78 \\
Variasi 2 & 1 & 8.00 & 4.66 & 0.79 & 1.15 & 0.74 \\
& 2 & 8.01 & 4.02 & 0.75 & 1.15 & 0.70 \\
& 3 & 7.81 & 7.34 & 0.86 & 1.18 & 0.82 \\
& 4 & 7.82 & 4.98 & 0.80 & 1.18 & 0.74 \\
\hline
\end{tabular}




\begin{tabular}{ccccccc}
\hline Perlakuan & Percobaan & Cs $(\mathbf{m g} / \mathbf{L})$ & $\mathbf{r}$ & $\mathbf{E}$ & $\mathbf{f}$ & $\mathbf{E}_{\mathbf{2 0}}$ \\
\hline \multirow{6}{*}{ Variasi 3} & 5 & 7.90 & 5.12 & 0.80 & 1.16 & 0.75 \\
& 1 & 8.04 & 6.43 & 0.84 & 1.15 & 0.80 \\
& 2 & 8.05 & 5.69 & 0.82 & 1.14 & 0.78 \\
& 3 & 7.77 & 12.58 & 0.92 & 1.18 & 0.88 \\
& 4 & 7.84 & 6.24 & 0.84 & 1.18 & 0.79 \\
& 5 & 7.92 & 6.46 & 0.85 & 1.16 & 0.80 \\
Variasi 4 & 1 & 8.08 & 5.09 & 0.80 & 1.14 & 0.76 \\
& 2 & 5.10 & 5.24 & 0.81 & 1.14 & 0.77 \\
& 3 & 7.79 & 7.85 & 0.87 & 1.18 & 0.82 \\
& 4 & 7.84 & 4.78 & 0.79 & 1.18 & 0.74 \\
& 5 & 7.81 & 5.43 & 0.82 & 1.18 & 0.76 \\
\hline
\end{tabular}

Pada percobaan yang dilakukan konsentrasi jenuh oksigen yang terhitung berkisar antara 7,77 mg/L sampai $8,10 \mathrm{mg} / \mathrm{L}$. Defisit rasio (r) adalah perbandingan antara selisih nilai DO sebelum dan setelah dilakukan aerasi $(\mathrm{Cd}-\mathrm{Cu})$ terhadap selisih antara nilai DO sebelum aerasi dan kandungan aerasi jenuh $(\mathrm{Cs}-\mathrm{Cu})$. Defisit rasio ini dapat menggambarkan seberapa banyak kenaikan (selisih) dari sebelum hingga sesudah dilakukan aerasi, semakin tinggi nilai $r$ maka semakin tinggi pula kenaikan DO pada saat aerasi dilakukan yang dapat dipakai sebagai kadar pengukuran kinerja suatu cascade aerator. Berdasarkan Tabel 3, defisit rasio yang dihasilkan dari aerasi dengan cascade aerator ini berkisar antara 3,86 hingga 12,58. Nilai ini jauh lebih besar dibandingkan penelitian sebelumnya yaitu 1,12 hingga 1,91 pada penelitian oleh Kim (2001).

Efisiensi (E) adalah seberapa banyak DO yang dapat dinaikan oleh suatu cascade aerator dari sebelum $(\mathrm{Cu})$ hingga setelah $(\mathrm{Cd})$ dilakukan aerasi dimana kadar maksimum kenaikan aerasi yang dipakai yaitu kandungan oksigen jenuh (Cs), sedangkan $\mathrm{E}_{20}$ menyatakan efisiensi pada suhu $20^{\circ} \mathrm{C}$. Pada percobaan ini efisiensi berkisar antara 74-92\% dan $\mathrm{E}_{20}$ berkisar antara 68-88\%. Pada pengukuran lapangan yang dilakukan oleh Gulliver dan Rinderls (1993) pada beberapa DAM dengan struktur spillway, didapatkan bahwa rentang efisiensi suatu terjunan dalam mengaerasi yaitu berkisar antara 28 hingga $93 \%$, hanya saja pengukuran ditempat yang memiliki suhu berbeda. Setelah disetarakan menjadi $\mathrm{E}_{20}$ rentang berubah antara 41 hingga 99\%. Hal ini menyatakan bahwa cascade aerator yang dipakai pada penelitian ini memiliki kinerja yang stabil karena memiliki efisiensi $\mathrm{E}_{20}$ cukup tinggi yaitu diatas $70 \%$ pada bak yang divariasikan. Kemudian rata-rata nilai defisit rasio, efisiensi dan efisiensi pada suhu $20^{\circ} \mathrm{C}$ disajikan pada Tabel 4.

Tabel 4 Rata-rata Hasil Perhitungan Nilai Defisit Rasio (r), Efisiensi (E) dan Efisiensi pada Suhu $20^{\circ} \mathrm{C}$ $\left(\mathrm{E}_{20}\right)$ pada Setiap Variasi

\begin{tabular}{cccc}
\hline Perlakuan & r & E & $\mathbf{E}_{\mathbf{2 0}}$ \\
\hline Kontrol & 4.67 & 0.78 & 0.72 \\
Variasi 1 & 6.22 & 0.83 & 0.78 \\
Variasi 2 & 5.22 & 0.80 & 0.75 \\
Variasi 3 & 7.48 & 0.85 & 0.81 \\
Variasi 4 & 5.68 & 0.82 & 0.77 \\
\hline
\end{tabular}

Berdasarkan Tabel 3, variasi 3 (slooping spillways dengan chute blocks) memiliki kinerja tertinggi baik dari defisit rasio maupun efisiensi. Variasi 3 memiliki nilai $r$ tertinggi yaitu 12,8 dengan efisiensi maksimal E sebesar $92 \%$ dan $\mathrm{E}_{20}$ sebesar $88 \%$. Kemudian berdasarkan Tabel 4, secara rata-rata kinerja 
variasi 3 juga terbaik dengan rata-rata nilai r yaitu 7,48 dengan efisiensi E sebesar $85 \%$ dan $\mathrm{E}_{20}$ sebesar $81 \%$.

Hasil penelitian menunjukan, bahwa variasi terbaik adalah variasi 3 yaitu invasi bak terjunan dengan adanya penambahan spillway yang dilengkapi dengan chute blocks. Menurut penelitian, melakukan inovasi pada bak terjunan juga mampu meningkatkan kinerja cascade aerator berbasis weir yang memiliki bak terjunan. Hal ini dapat dilihat bahwa semua variasi menunjukan peningkatan kinerja apabila dibandingkan dengan kontrol.

Ini disebabkan karena dengan mengubah bak terjunan maka akan berubah pula pola sirkulasi air, bentuk jatuh serta gelembung yang dihasilkan yang mempengaruhi pengikatan oksigen dan air. Perubahan pola aliran ini juga mempengaruhi turbulensi air seperti yang dijelaskan oleh Kindsvaler dalam ASCE (1991), ada beberapa proses fisik dasar dan hidrodinamik yang mengakibatkan transfer gas pada alat berbasis hidrolik yaitu pencampuran turbulen (turbulent mixing) pada permukaan air dengan badan air pada aliran, peningkatan transfer massa dari terbentuknya gelembung udara (bubble) dan akibat tekanan hidrostatik dari tailwater. Pola sirkulasi air di dalam bak aerator dapat digambarkan oleh Gambar 4.

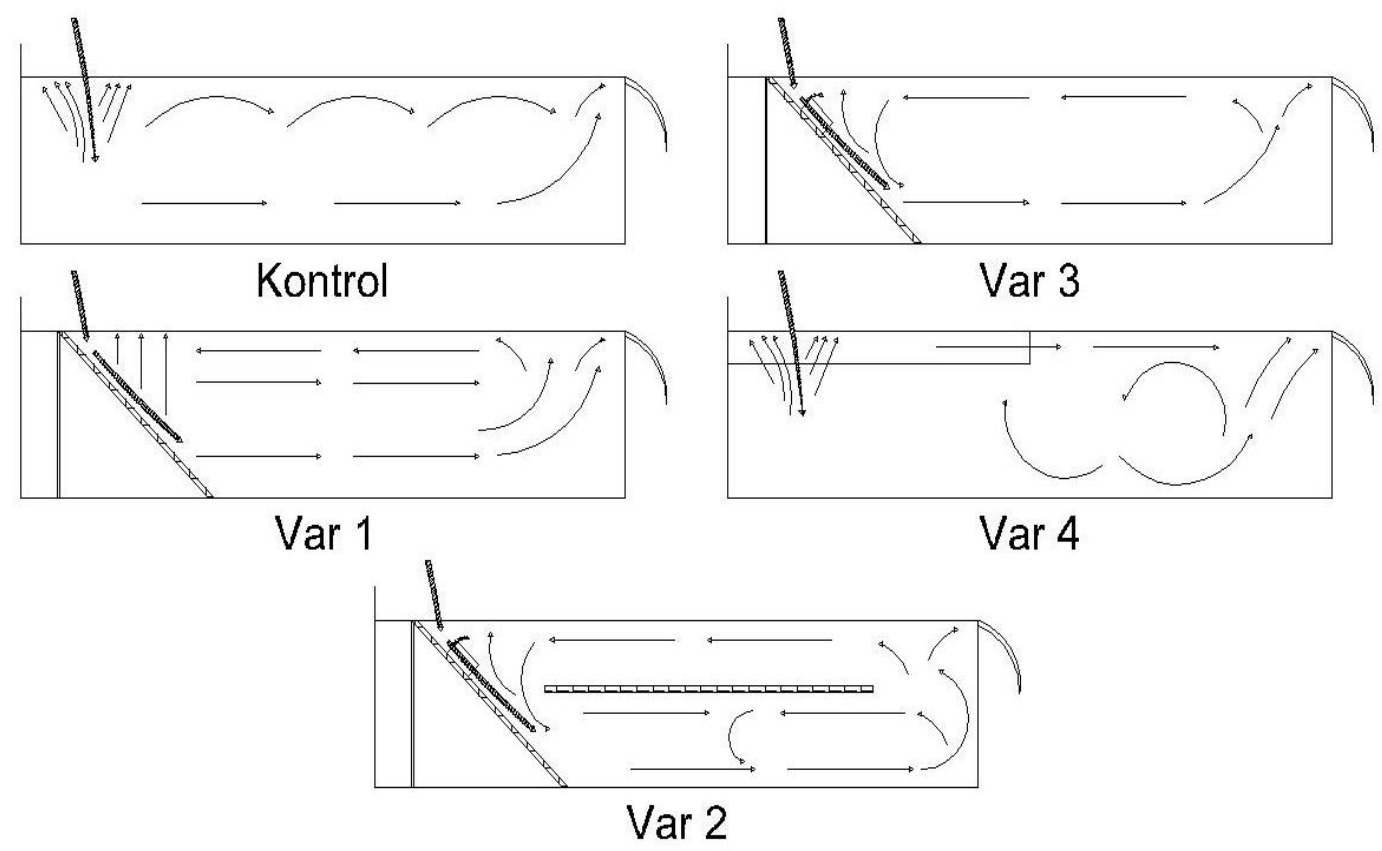

Gambar 4 Pola Sirkulasi Aliran di dalam Bak Aerator menurut Bentuk Variasi Bak

Berdasarkan pola sirkulasi yang terlihat, variasi 3 memiliki pola sirkulasi aliran yang paling sedikit kehilangan energi kinetik aliran dan dengan pola memutar tunggal dibandingkan dengan variasi lainnya. Hal itu menyebabkan variasi ini memiliki hambatan terkecil sehingga dengan lancarnya aliran air, kontak oksigen dengan air semakin baik (Haryanto, 2005). Pola yang seperti ini dapat ditemukan pada basin yang memiliki tenaga dorong yang tinggi dan pada hal ini dapat dilakukan dengan penambahan slooping spillway yang akan meningkatkan arus bawah sehingga memutar balik arus yang alin. Arus memutar balik ini menghalangi arus atas sehingga arus atas yang harusnya kedepan merubah arah putaran mengikuti pola putaran arus bawah sehingga tercipta aliran memutar seperti yang terlihat pada variasi 1, 2 dan 3. Hanya saja pada variasi 1 dan 2, kecepatan aliran tidak terlalu kuat. Pada variasi 3 ada tambahan dorongan akibat air yang meloncat pada chute block yang tidak dimiliki oleh variasi 1. Sedangkan variasi 2 pola berubah akibat adanya horizontal plate block yang meningkatkan gaya gesek air dan bahan block sehingga menurunkan kekuatan arus serta merubah pola sirkulasi aliran. 
Untuk membandingkan penyebab kinerja aerator, juga dilakukan pengamatan pada residensi gelembung dapat dilihat pada Tabel 5.

Tabel 5. Hasil Pengamatan Langsung pada Proses Aerasi Setiap Variasi

\begin{tabular}{|c|c|c|c|c|c|c|c|c|}
\hline Variasi & $\begin{array}{c}\text { Panjang } \\
\text { Tailwater } \\
\text { (cm) }\end{array}$ & $\begin{array}{c}\text { Panjang } \\
\text { Aerasi } \\
\text { (cm) }\end{array}$ & $\begin{array}{l}\text { Tenaga } \\
\text { Awal }\end{array}$ & $\begin{array}{l}\text { Pusaran } \\
\text { Sirkulasi }\end{array}$ & Hambatan & $\begin{array}{c}\text { Kecepatan } \\
\text { Sirkulasi }\end{array}$ & $\begin{array}{c}\text { Residensi } \\
\text { Gelembung }\end{array}$ & $\mathbf{E}$ \\
\hline Kontrol & 14 & 16 & Sedang & 0 & Kecil & Kecil & Pendek & $\begin{array}{c}0.7 \\
8\end{array}$ \\
\hline Var 1 & 28 & 25 & Besar & 2 & Kecil & Sedang & Sedang & $\begin{array}{c}0.8 \\
3\end{array}$ \\
\hline Var 2 & 20 & 12 & Besar & 2 & Besar & Sedang & Sedang & $\begin{array}{c}0.8 \\
0\end{array}$ \\
\hline Var 3 & 27 & 28 & Besar & 1 & Kecil & Besar & Panjang & $\begin{array}{c}0.8 \\
5\end{array}$ \\
\hline Var 4 & 12 & 36 & Sedang & 2 & Besar & Sedang & Sedang & $\begin{array}{c}0.8 \\
2\end{array}$ \\
\hline
\end{tabular}

Berdasarkan Tabel 5, ada hubungan antara panjang tailwater, tenaga awal, pola sirkulasi, besar hambatan, kecepatan dan residensi gelembung terhadap kinerja cascade aerator. Panjang tailwater yang didapat dari pengukuran tailwater mengambarkan seberapa besar tenaga awal yang mampu dihasilkan oleh cascade aerator akibat adanya variasi pada bak terjunan. Panjang tailwater ini kemudian direntangkan menjadi rentang tenaga awal, dimana panjang tailwater dibawah $10 \mathrm{~cm}$ mengindikasikan tenaga awal rendah, panjang tailwater antara 10 hingga $20 \mathrm{~cm}$ sebagai tenaga awal sedang dan pangjang tailwater diatas $20 \mathrm{~cm}$ sebagai tenaga awal besar. Jumlah pusaran/sirkulasi menggambarkan seberapa banyak pusaran yang terjadi yang didapat dari Gambar 4. Hambatan menggambarkan seberapa banyak penghambat aliran yang berupa hambatan friksi yang terjadi antara air dan struktur pada bak aerasi. Kemudian kecepatan sirkulasi merupakan hasil interaksi antara tenaga awal, pola sirkulasi dan hambatan yang mengambarkan seberapa cepat aliran sirkulasi yang terjadi. Semakin besar tenaga aliran semakin baik kecepatan sirkulasi, semakin sedikit pusaran juga semakin baik karena awal kecepatan tidak akan terbagi ke beberapa pusaran sertasemakin kecil hambatan maka semakin baik pula kecepatan sirkulasi karena tidak adanya factor yang menciptakan headloss pada kecepatan sirkulasi. Sedangkan waktu residensi didapat dari interaksi antara pola sirkulasi yang terjadi dengan kecepatan sirkulasi serta sifat gelembung yang dihasilkan.

Kecepatan sirkulasi, variasi 3 memiliki kecepatan sirkulasi yang baik dan stabil. Variasi 1, 2 dan 3 memang memiliki tenaga awal yang paling besar, hal ini dapat dilihat dari panjang tailwater yang dihasilkan. Pada kontrol dan variasi 4 tenaga awal rendah terlihat pada panjang tailwater yang termasuk rentang sedang. Kemudian karena pada variasi 3 hanya terdapat 1 pola sirkulasi, sedangkan pada variasi lain terdapat banyak arus yang keluar dari pola sirkulasi dan juga pola sirkulasi yang terjadi lebih dari satu, sehingga akan mempengaruhi kecepatan sirkulasi dimana kecepatan sirkulasi akan menurun dibandingkan dengan variasi 3. Semakin banyak pola sirkulasi maka kecepatan aliran akan berkurang. Pada variasi 2 dan 4 juga mengalami banyak hambatan yang berasal dari struktur alat yang menyebabkan kenaikan headloss akibat friksi yang mengurangi kecepatan sirkulasi. Pada kontrol tidak ada kecepatan sirkulasi hanya ada kecepatan aliran yang kekuatannya sedang karena kecilnya hambatan, tetapi kecepatan aliran tidak besar juga karena tenaga awal yang rendah. Pada kontrol juga tidak bisa disebut kecepatan sirkulasi karena tidak adanya sirkulasi sempurna yang terjadi.

Setelah menghubungkan antara pola sirkulasi yang terjadi pada Gambar $\mathbf{4}$ dengan hasil pengamatan kecepatan sirkulasi pada Tabel 5, penyebab utama tingginya kinerja variasi 3 terjadi akibat waktu residensi gelembung yang panjang. Hal ini karena secara derajat turbulensi variasi 3 unggul dengan tenaga awal yang besar, hambatan kecil dan kecepatan sirkulasi yang tinggi serta pola sirkulasi yang 
sedikit dalam hal kehilangan energi dan stabil sehingga gelembung terus berputar beberapa kali mengikuti pola aliran sebelum keluar mengikuti arus menuju outlet. Pada variasi 1, 2 dan 4 sebenarnya juga terjadi hal seperti ini, tetapi akibat pola pusaran yang banyak kehilangan energi dan berkurangnya kecepatan, banyak gelembung yang akan keluar mengikuti arus ke outlet karena arus ke outlet lebih kuat dibandingkan arus sirkulasi dan mengurangi waktu residensi gelembung. Terlebih pada variasi 2, ada gelembung yang tertahan pada block yang dimaksudkan memang untuk memperpanjang waktu residensi. Tetapi gelembung tersebut malah gagal berresidensi dan malah bergabung dengan gelembung yang lain menjadi gelembung besar yang tidak bisa terikat dengan air dan menempel di block. Sedangkan pada kontrol, residensi gelembung sangat pendek karena tidak ada sirkulasi air yang terjadi pada bak sehingga gelembung langsung keluar dari bak mengikuti arus ke outlet dan tidak sempat terikat dengan air. Panjang waktu residensi gelembung sangat berpengaruh terhadap pengikatan oksigen dan air, dimana semakin lama gelembung berada dalam air maka semakin baik pula tranfer oksigen yang terjadi (Kossay, 2016).

Ukuran butiran dan jumlah gelembung juga berpengaruh terhadap transfer oksigen (Wijayanti, 2015), tetapi hasil pengamatan pada gelembung yang didapatkan sangat sulit untuk dicari perbedaannya. Hasil pengukuran gelembung dapat dilihat pada Gambar 5.

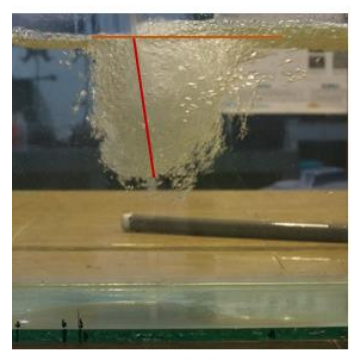

(Kontrol)

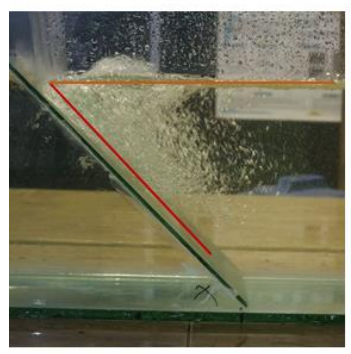

(Variasi 3)

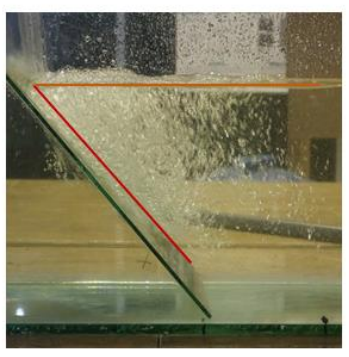

(Variasi 1)

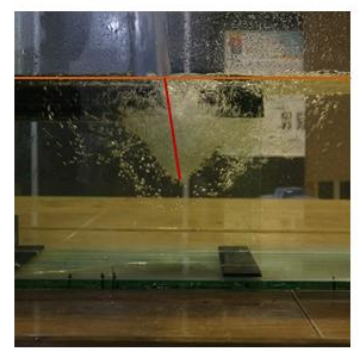

(Variasi 4)

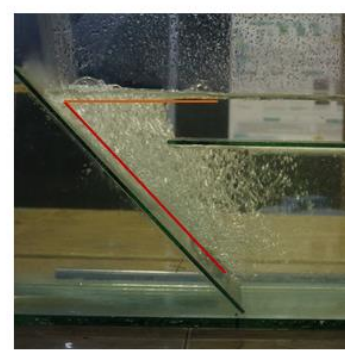

(Variasi 2)

Keterangan:

- Panjang Tailwater

- Panjang Aerasi

Gambar 5 Bentuk Tailwater dan Gelembung

Berdasarkan Gambar 5, gelembung yang dihasilkan oleh variasi 1, 2 dan 3 memiliki ukuran yang lebih kecil, sedangkan variasi 4 sedikit besar dan variasi 1 gelembung terbesar. Hal ini karena pada variasi 1, 2 dan 3 terjadi hempasan antara aliran air datang dan slooping spillway yang lebih padat. Terlebih pada variasi 3, terdapat chute block yang menghempaskan lebih kuat dan memecah air menjadi gelembung yang lebih kecil. Pada variasi 4, tumbukan terjadi tetapi tidak terlalu besar karena bidang hempasan yang lebih kecil. Sedangkan pada kontrol, ukuran gelembung besar karena tumbukan antara air yang datang dan air di bak tidak lebih kuat dibandingkan dengan tumbukan terhadap benda padat. Ukuran gelembung mempengaruhi pengikatan air dan oksigen, dimana gelembung dengan ukuran yang lebih kecil memiliki pengikatan yang lebih baik (Sinaga, 2018). Ukuran gelembung juga mempengaruhi laju naik gelembung, gelembung yang berukuran besar memiliki laju naik yang tinggi (Wijayanti, 2015) sehingga memiliki waktu residensi yang rendah. 


\section{KESIMPULAN DAN SARAN}

\section{Kesimpulan}

Berdasarkan hasil pembahasan yang telah diuraikan, kesimpulan pada penelitian ini antara lain:

1. Bentuk bak terjunan berpengaruh terhadap kinerja cascade aerasi yang ditunjukkan dengan nilai peningkatan DO, defisit rasio dan efisiensi. Variasi 1 slooping spillway mampu menaikan kinerja cascade aerator dengan rata-rata selisih DO sebesar 2,94 mg/L, defisit rasio sebesar 6,22, efisiensi sebesar $83 \%$ dan efisiensi pada suhu $20^{\circ} \mathrm{C}$ sebesar $78 \%$. Variasi 2 slooping spillway dengan horizontal plate block memiliki rata-rata selisih nilai DO 2,88 mg/L, defisit rasio sebesar 5,22, efisiensi sebesar $88 \%$ dan efisiensi pada suhu $20^{\circ} \mathrm{C}$ sebesar $75 \%$. Variasi 3 slooping spillway dengan chute blocks memiliki kinerja dengan rata-rata selisih nilai DO 3,08 mg/L, 2 defisit rasio sebesar 7,48, efisiensi sebesar $85 \%$ dan efisiensi pada suhu $20^{\circ} \mathrm{C}$ sebesar $81 \%$. Variasi 4 pemecah aliran memiliki kinerja dengan selisih nilai DO sebesar $2,95 \mathrm{mg} / \mathrm{L}$, defisit rasio sebesar 5,68, efisiensi sebesar $82 \%$ dan efisiensi pada suhu $20^{\circ} \mathrm{C}$ sebesar $77 \%$. Sedangkan kontrol memiliki kinerja dengan selisih nilai DO sebesar 2,74 mg/L, defisit rasio sebesar 4,67, efisiensi sebesar 78\% dan efisiensi pada suhu $20^{\circ} \mathrm{C}$ sebesar $72 \%$

2. Bentuk bak terjunan terbaik terdapat pada variasi 3 yaitu slooping spillway dengan chute block dengan rata-rata peningkatan DO sebesar 3,08 mg/L, defisit rasio sebesar 7,48, efisiensi sebesar $85 \%$ dan efisiensi pada suhu $20^{\circ} \mathrm{C}$ sebesar $81 \%$.

\section{Saran}

Pelaksanaan penelitian sebaiknya tidak menggunakan pompa, karena pompa menghasilkan sedikit gelembung akibat adanya gelembung yang terperangkap pada pipa sehingga ditakutkan dapat mempengaruhi kadar DO awal. Alternatif penghasil aliran dapat menggunakan tangki atas sehingga aerasi mendekati keadaan alaminya yaitu menggunakan tenaga gravitasi.

\section{DAFTAR PUSTAKA}

Abuzar, S.S., Putra, Y.D., dan R.E. Emargi. 2012.Koefisien Transfer Gas (KLa) pada Proses Aerasi menggunakan Tray Aerator Bertingkat 5 (Lima). Jurnal Teknik Lingkungan UNAND 9(2), 155163.

Alfana, M.A.F., Cahyadi, A., Budiani, S.R., Darda., dan A.K. Wati. 2016. Pengembangan Sistem Aerasi untuk Penurunan Kandungan Besi dalam Air Tanah. Universitas Gadjah Mada: Yogyakarta.

Bennefield, L.D., Randall, C.W. 1980. Biological Process Design for Wastewater Treatment. PrenticeHall, Inc, Englewood Cliffs, NJ 07632.

Fair, G.M., Geyer, J.C., dan D.A. Okun. 1968. Water and Wastewater Engineering. Water Purification and Wastewater Treatment and Disposal. Jhon Wiley \& sons Inc: New York.

Gameson, A.L.H. 1957. Weirs and Aerations of River. J. Ins. Of Water Engrg 11(5), 477-490.

Guliver, J.S., dan A.J. Rindels. 1993. Measurment of Air-Water Oxigen Transfer at Hydraulic Structures. Journal of Hydraulic Engineering 199(3), 327.

Kossay, A. 2006. Analysis of Oxygen Transfer Performance on Sub-surface Aeration Systems. International Journal of Environment Research and Public Health 3(8), 301. 
Hartini, Eko. 2012. Cascade Aerator dan Bubble Aerator dalam Menurunkan Kadar Mangan Air Sumur Gali. Jurnal Kesehatan Masyarakat 8(1), 44-52.

Haryanto, E. 2005. Pengaruh Bentuk Difuser Terhadap Transfer Oksigen. Jurnal Rekayasa Perencanaan 2(1), 33-46.

Kim, J., dan R.W. Walters. 2001. Oxygen Transfer at Low Drop Weirs. J.Environ.Eng 127(1), $604-$ 610.

Kindsvaler., C.E. 1991. The Hydraulic-Jump in Slooping Channels. ASCE 109(1), 1107-1944.

Mays, L.W. 2019. Water Resources Engineering. Arizona: Arizona State University.

Metcalf, E. 2003. Wastewater Engineering Treatment and Reuse. Mc.Graw Hill: New York.

Peterka, A.J. 2005. Hydraulic Design of Spillways and Energy Dissipators, U.S. Bureau of Reclamation 1964. University Press of The Pacific: Washington D.C.

Said, N. 2003. Metode Praktis Penghilangan Zat Besi dan Mangan di Dalam Air Minum. Jakarta: Kelair BPPT.

Scott, M.L., Nesheim, M.C. dan R.J. Young. 1982. Nutrition of Chiken. Newyork: Ithaca Publisher.

Sulaksono, F. Pengaruh Tinggi Step pada Metode Aerasi Cascade Terhadap Penurunan Kadar Besi Terlarut dalam Air Sumur Gali. Universitas Indonesia: Depok.

U.S. Bureau of Reclamation. 1987. Design of Small Dams, Edisi Ke-3. U.S Government Printing Office: Washington D.C.

Yatie, A.E. 2012. Transfer Oksigen pada Cascade Aerator [SKRIPSI]. Surabaya: Universitas Pembangunan Nasional "Veteran" Jawa Timur.

Wijayanti, Y. 2015. Pengaruh Debit Terhadap Dinamika Gelembung Udara dalam Kolom Aerator. Universitas Islam Indonesia: Yogyakarta. 